\title{
Information Literacy Instruction for an Honors Program First-Year Orientation: Lessons Learned over 15 Years of a Sustainable Partnership
}

Anna Marie Johnson

University of Louisville, amj42@iu.edu

\section{Recommended Citation}

Johnson, A. (2013). Information Literacy Instruction for an Honors Program First-Year Orientation: Lessons Learned over 15 Years of a Sustainable Partnership. Communications in Information Literacy, 6 (2), 141-150. https://doi.org/10.15760/comminfolit.2013.6.2.124

This open access Perspective is distributed under the terms of the Creative Commons Attribution-NonCommercialShareAlike 4.0 International License (CC BY-NC-SA 4.0). All documents in PDXScholar should meet accessibility standards. If we can make this document more accessible to you, contact our team. 


\title{
INFORMATION LITERACY INSTRUCTION FOR AN HONORS PROGRAM FIRST-YEAR ORIENTATION
}

\section{Lessons learned over 15 years of a sustainable partnership}

Anna Marie Johnson

University of Louisville

\begin{abstract}
The information literacy literature contains many articles highlighting new instruction initiatives but few articles documenting sustainable ones. This article examines the literature on library partnerships in general and Honors Programs specifically and reports on the evolution of an ongoing fifteen year partnership between the University of Louisville Honors Program and the Ekstrom Library. It then discusses the development of this partnership and the changes in the information literacy program engendered by this partnership. It ends by defining some of the elements that made the partnership sustainable, ones that could potentially be transferred to other such partnerships.
\end{abstract}




\section{INTRODUCTION}

Only rarely in the literature on information literacy does one see how a program of instruction has changed or evolved. Generally, articles or book chapters provide only a "snapshot" view of a programmatic initiative. That same initiative is not often revisited in the literature, either because it is ultimately unsuccessful, because the author has moved on to a new library, or perhaps because it is ongoing and thus not newsworthy. Sustainability, the ability to maintain an ongoing program of instruction in the long-term, is often cited as a challenge in instruction partnerships (Bruch \& Frank, 2011). Although the University of Louisville's (UofL) Ekstrom Library Information Literacy Program has been involved in ongoing partnerships with several academic programs, the involvement with the Honors Program is probably the most successful overall. The Honors Program, a program for promising first year students who meet the minimum standardized test and GPA requirements, has partnered with the library to provide a library orientation every year for the past fifteen years. Each year, Honors sponsors a mandatory first-year orientation weekend prior to the start of the fall semester. That orientation has undergone changes in response to student feedback, but the library has always been included. The library's involvement with the Honors Program orientation has undergone significant revision and realignment that mirror the IL instruction program's overall shift from a focus on teaching particular library tools to a conceptual approach to information seeking. Most importantly, both the Honors Program and the library have committed to creating an ongoing, sustainable partnership.

\section{LITERATURE REVIEW: LIBRARY IL COLLABORATIONS}

Articles describing collaboration and partnerships are numerous in the information literacy and library instruction literature, comprising $10 \%$ and $20 \%$ of the literature in 2005 and 2009 respectively (A. M. Johnson \& Jent, 2007; A. M. Johnson, Sproles, \& Detmering, 2010). Beginning with Raspa and Ward's call to action, many librarians have taken up the challenge of building partnerships to advance information literacy (2000). Most partnerships in the higher education IL literature involve faculty (Mounce, 2010), and some articles point to successful elements of those types of partnerships (Black, Crest, \& Volland, 2001; Brasley, 2008; Ivey, 2003; Machin, 2009; Simon, 2009) while others focus on the aspects of the partnership such as the technology or the project outcome rather than the partnership itself (Barratt, Nielsen, Desmet, \& Balthazor, 2009; Blummer, 2007; Simon, 2009; Tooman \& Sibthorpe, 2012). Still others deal with partnerships involving programs or departments (M. Johnson, Clapp, Ewing, \& Buhler, 2011; Love \& Edwards, 2009; Swartz, Carlisle, \& Uyeki, 2007; Witt \& Dickinson, 2003). A number of articles specifically address librarians meeting the research and instruction needs of honors students. Yee (1984) calls for a "close alliance" between the library and the Honors Department and suggests that instruction should focus on the development of transferable problem-solving skills. Contrary to popular perception, honors students do need some amount of information literacy instruction. A project at Rutgers in the late 1980 s with voluntary library instruction seminars found that honors students were not any more advanced in their bibliographic skills when compared with non-honors students (Wilson 
\& Mulcahy, 1987). Snavely and Wright echo this finding when they describe their for-credit Honors research seminar (Snavely \& Wright, 2003).

Many of the articles written about library instruction for honors students involve partnerships or collaboration; however, most of them do not focus on this aspect of the instruction. Creating course-integrated modules (Loomis and Herrling (1993), a three-session sequence for a one-credit colloquium (Bush \& Wells, 1990), and library involvement in planning and grading assignments in an honors course (Woodard, 1996) have all been discussed. Consulting approaches (Isbell, 2009; Kraemer, 2007), voluntary seminars (Riehle, 2008), seminars on special topics (Carlin \& Damschroder, 2009) and course-integrated instruction (C. M. Johnson, Anelli, Galbraith, \& Green, 2011) are all variations of partnering that are described in the literature about working with honors programs.

Although collaboration and partnership with an honors program is implicit in most of the above articles, articles describing long-term partnerships between the library and any type of program such as the one at the UofL are few and far between. Even more difficult to find are articles that provide advice or guidance on maintaining longterm relationships.

\section{The Evolution of A PARTNERSHIP}

The experience of the Ekstrom Library reflects both the evolution of a library instruction program and the give-and-take involved in a campus partnership as is evident from the history of this relationship.

The campus-wide Honors Program at UofL was created in 1982 and currently enrolls more than 750 students each semester (University of Louisville, 2012b). The University of Louisville is a southeastern university with an enrollment of 18,454 (FTE) students. UofL Libraries consists of six libraries, approximately 40 librarians, and 75 professional staff. Ekstrom Library's involvement with the Honors Program firstyear orientation began in 1997 when three librarians taught two-hour sessions on email and using the Internet for research. At that time, both student email and the Internet were fairly new and no one else on campus was equipped to teach students how to use these tools. Anecdotal evidence indicated that the students had enjoyed the sessions but were eager for more information about the libraries themselves. Consequently, the Honors Program extended the time allotted for the session the following year to include a short auditorium-style session on website evaluation and a "Library Expedition" where students visited various library locations and got their "Information Passport" stamped. While this was certainly much more active, it was obviously less than ideal to have all the honors students wandering the library at the same time. The students were simply being asked to visit the locations without completing any kind of learning exercise. No assessment was conducted and it was difficult to discern if learning was taking place.

In 1999, the model was quite similar but with important refinements. The Honors Program and the library worked together to find a schedule that would allow three consecutive sessions so that the groups for the website evaluation piece could be smaller and allow for discussion. The library session involved a much more substantial amount of preparation on the part of the librarians but it provided a considerably enhanced active learning experience for students. Thirty different 
exercises designed by librarians for each of eight themes (e.g. "Terrorism in the Middle East" or "Documentary Photography") meant that students were divided into smaller teams (5 students each) and spaced evenly throughout the library. In keeping with the philosophy of the information literacy program at the time, the goal of this experience was for students to receive hands -on instruction in a number of research tools. After completing the exercise, the small teams of students had ten minutes to summarize what they had learned. Each team then presented their findings to the larger group.

This effort represented the IL program's move to a more active pedagogy while still maintaining a focus on the tools such as the catalog and databases. As formal assessment was playing a more prominent role in the information literacy program, a formal evaluation of the Honors Orientation was used. It indicated that some parts of the library experience were successful. For example, $88 \%$ of the students thought the exercise was just right and $97 \%$ were able to identify the library's catalog by name while $85 \%$ could name 3 of the 5 evaluation criteria taught them. Students also seemed to enjoy getting to explore the library. Other parts were not as successful in that some students felt the exercise was "too competitive" and only 51\% understood that citations for periodical articles are not found in the catalog. With some small changes to address these issues, this same formula was used for the orientation in 2000 as well. (For more description of these efforts, see Johnson, A.M. \& Laning, M. (2000) and Holtze, T.L. \& Johnson, A.M. (2002)).

In 2001 the Honors Program rearranged their schedule for the orientation weekend as well as the addition of the theme "City as Text." The result of these changes was that the library portion of the orientation needed to be condensed. While this wasn't ideal, the importance of working with the Honors Program necessitated flexibility on the part of the Library. The students still were able to get some hands-on experience as their visit incorporated government documents, microfilm, reference, stacks, an instructional computer lab, and one of the special collections. The instructional lab portion was a fairly traditional library instruction session involving an introduction to research via a general purpose article database and a short segment on the library catalog. It also included a four question assessment of the student's learning which showed that students were still somewhat confused about whether they could find article citations in our catalog.

The Honors Program received feedback from their students that the entire orientation weekend was too long, requiring them to shorten all parts of the schedule. The shorter amount of time allotted to the library introduction in 2002 and an increased Honors enrollment required more creativity on the librarians' part. The Library's part of the session was honed to its key components: primary and secondary sources. During the sessions, the students rotated between an instructional lab, where they were led through a discussion and demonstration of secondary sources, and one of the library's special collection areas where they learned about research using primary sources. While this development might seem negative from the library's perspective, it actually resulted in a very positive change: the addition of a librariandesigned writing assignment that the students complete in the first weeks of the semester on their own time.

This assignment asks the students to find a scholarly journal article, a book, and some 
piece of primary source material on the same theme or topic. The goals listed at the beginning of the assignment include:

- Identifying a variety of types and formats of potential sources for information.

- Using various search systems to retrieve information in a variety of formats.

- Identifying the purpose and audience of potential sources.

- Differentiating between primary and secondary sources.

- Understanding that information may need to be constructed with raw data from primary sources.

In practice, the assignment asks students to reflect in a short (500-750 word) paper both on the process of finding the material (i.e. "process of defining question, planning your search, and evaluating the materials themselves") and on what they learned from the three "texts" they chose, including additional questions that were raised in the process of their research. This approach was designed to help the students see the connections between primary sources and secondary sources. In a very small but significant way, it also attempted to replicate the process that scholars use when they are thinking about a topic. In fact, the assignment guidelines explicitly state that students "might work through the processes of inquiry, research and reflection that are at the heart of university intellectual life."

From 2001 to 2011 this same model continued to be used. The assignment was adapted every year to match the faculty's chosen course themes, and it additionally served as a mode of assessment. Sometimes the rotation of how students moved through the library was altered and in 2005 an additional section for business students was accommodated. In order to align with UofL's accreditation effort (University of Louisville, 2012a), in 2009, the assignment was tweaked to emphasize the Richard Paul and Linda Elder Critical Thinking Model (2009). After discussions with the Honors Program, an exciting development occurred in 2012 when the two segments of the experience (special collections visit and a session in the instruction computer labs) were scheduled at different times to better equip students to complete the library assignment. Now the special collections visit occurs during the orientation weekend, but the instructional lab session occurs in the second week of the semester when the students are beginning their assignments. This was a significant and important change negotiated by the librarians in order to better facilitate the timing of the session to coincide with when the students were the most receptive to instruction.

In many ways, the evolution of the Honors library orientation has mirrored the evolution of the Ekstrom Library's information literacy pedagogy. In the beginning of the partnership, the librarians' focus was on teaching students the tools involved in library research. The practice has shifted over time and while library research tools and finding aids are still part of the instruction, the focus is now on thinking critically and reflectively throughout the research process.

\section{SUSTAINABILITY: THE HOLY GRAIL}

What has made this partnership sustainable? Certainly the combination of this particular group of students and some continuity in both Honors and Library personnel have helped, but there are other, less specific elements that stand out. Some of the elements remind one of a good marriage and 
many of them apply to information literacy instruction in general, but they still bear emphasizing. This list shares some items in common with Ivey's four behaviors found in "successful, collaborative partnerships" (2003).

1) Flexibility: the library's willingness to adapt as well as the Honors Program's flexibility with scheduling. Even though the library has probably adapted more than the Honors Program, the Honors Program has had its own pressures (additional student enrollment, student feedback, etc.) and still has continued to accommodate IL instruction.

2) Commitment: Commitment to this experience on the part of both the library and the Honors Program. Both parties feel that this experience is important enough that we continue to commit personnel and time to it each year.

3) The Population: Honors students are more likely to do research and thus have a greater need for this type of experience. For this reason it may be an easier "sell" to them, as opposed some other special populations.

4) Mutual Goals: Both the library and the Honors Program want the students to be well-prepared for library research at UofL. Both of the parties also want to emphasize to these students that they have chosen well in their choice of university. This orientation ensures that all incoming Honors students have the beginnings of a foundation for library research and that they recognize the value of
UofL's research collections. Both parties also see how the library experience and the library assignment that students complete work toward meeting these goals.

5) Mutual Benefits: Prestige for both parties. To work with some of the brightest and most promising students on campus benefits the library; but the Honors Program benefits from their close relationship with the library as well in terms of the Library's more focused attention on supporting their curriculum, requests for rooms and other services, and a collection budget line dedicated to their program.

6) Perception of "Specialness": Honors students are a premier group of students on campus. Showing them some of UofL's treasures helps them feel that they are getting a special experience.

7) Communication: Although personnel have changed roles in both the library and the Honors Program, annual communication between the two parties has continued and neither party has borne the entire burden.

8) Structure: Both the Honors Program orientation weekend and the library experience piece are very carefully structured. This allows for continuity between course sections and also in designing the experience from year to year. 


\section{CONCLUSION}

Ekstrom Library has completed year ten of using essentially the same instruction model with the Honors Orientation. The structured nature of the library experience means the three departments primarily involved (Reference, Special Collections/Rare Books, and University Archives) spend a minimal amount of time planning each year. As librarians and Honors staff have come and gone or been away on leave, the communication and planning has not been dependent on any one individual. In fact, over the years, seven different librarians have coordinated the library's involvement. As the partnership has evolved, Ekstrom Library has achieved Yee's "close alliance"; the Library is an integral part of the Honors Program Orientation. This ongoing partnership has benefitted both the Honors Program and the library. For the library, the effort fosters annual communication, knowledge of the faculty and students in the program, and the prestige of being associated with the University's brightest students. The benefits for the first-year students in the Honors Program are knowledge of parts of the library most students never have access to; a chance to use library resources at the beginning of their college experience; and a unique library assignment. The sections of Honors students that complete the current assignment produce a rich set of authentic student-created research artifacts. Similar to Snavely and Wright's experience, these artifacts have provided a deeper insight into students' research abilities.

The evolution of the partnership with the Honors Program has mirrored the evolution of the information literacy program in general. Beginning with assignments and instruction focused on teaching specific tools, the instruction progressed to attempting to cover everything the students could ever possibly need to know about the library. Ekstrom Library's Information Literacy Program now concentrates on teaching students to think as a researcher, and to develop skills that are more about making connections between what they already know and what the librarians believe they should know. Our view of assessment has also moved from an evaluation of the students' experience, through using tool-based test type assessments, to a more holistic and integrated attempt to understand how students think about research. The constraints of the library-Honors partnership and evaluations of the students' experience helped create a sustainable and productive instructional model. This model is focused on structuring a discovery experience for students where they are able to use the information literacy instruction to make important connections for themselves as they are exploring the library's collections. Even though this model is not used with every course taught in the information literacy program, aspects of this philosophy have now been integrated into most lowerlevel instruction. This represents a less traditional, more progressive approach to information literacy that the library will continue to evaluate as needed. The library's involvement with the Honors Program has proven to be fortuitous, influential, productive, and most of all, sustainable.

\section{REFERENCES}

Barratt, C. C., Nielsen, K., Desmet, C., \& Balthazor, R. (2009). Collaboration is key: Librarians and composition instructors analyze student research and writing. portal: Libraries \& the Academy, 9(1), 37-56. doi: 10.1353/pla.0.0038. 
Black, C., Crest, S., \& Volland, M. (2001). Building a successful information literacy infrastructure on the foundation of librarianfaculty collaboration. Research Strategies, 18(3), 215-225. doi: 10.1300/ J106v14n03 03.

Blummer, B. (2007). Utilizing webquests for information literacy instruction in distance education. College \& Undergraduate Libraries, 14(3), 45-62.

Brasley, S. S. (2008). Effective librarian and discipline faculty collaboration models for integrating information literacy into the fabric of an academic institution. New Directions for Teaching \& Learning 2008 (114), 71-88.

Bruch, C., \& Frank, K. (2011). Sustainable collaborations: Libraries link dual-credit programs to P-20 initiatives. Collaborative Librarianship, 3(2), 90-97.

Bush, R. B., \& Wells, M. R. (1990). Bibliographic instruction for honors students: The University at Buffalo experience. Research Strategies, 8(3), 137143.

Carlin, J. A., \& Damschroder, C. B. (2009). Beautiful and useful: The book as a learning object: Using an honors seminar as a forum to explore information literacy and critical thinking. College \& Research Libraries News, 70(3), 168-183.

Holtze, T. L., \& Johnson, A.M. (2002). Teaching in another dimension: collaborating with the University Honors Program on freshman orientation. In J.K. Nims \& A. Andrew (Eds.), First Impressions, Lasting Impact: Introducing the First-Year Student to the Academic Library; National LOEX Conference. Ypsilanti, Michigan: Pierian Press.
Isbell, D. (2009). A librarian research consultation requirement for university honors students beginning their theses. College \& Undergraduate Libraries, 16(1), 53-57. doi: 10.1080/10691310902754072.

Ivey, R. (2003). Information literacy: How do librarians and academics work in partnership to deliver effective learning programs? Australian Academic \& Research Libraries, 34(2), 100-113.

Johnson, A.M. \& Laning, M. (2000). Recipe for disaster or formula for success? College \& Research Libraries News, 61(7), 597.

Johnson, A. M., \& Jent, S. (2007). Library instruction and information literacy -- 2005. Reference Services Review, 35(1), 137-186. doi: 10.1108/00907320710729427.

Johnson, A. M., Sproles, C., \& Detmering, R. (2010). Library instruction and information literacy 2009. Reference Services Review, 38(4), 676-768. doi: 10.1108/00907321011090809.

Johnson, C. M., Anelli, C. M., Galbraith, B. J., \& Green, K. A. (2011). Information literacy instruction and assessment in an honors college science fundamentals course. College \& Research Libraries, 72(6), 533547.

Johnson, M., Clapp, M. J., Ewing, S. R., \& Buhler, A. (2011). Building a participatory culture: Collaborating with student organizations for twenty-first century library instruction. Collaborative Librarianship, 3 (1), 2-15.

Kraemer, E. W. (2007). Developing information literacy instruction for honors students at Oakland University: An information consulting approach. College \& 
Undergraduate Libraries, 14(3), 63-73. doi: 10.1300/J106v14n03\&\#x201704.

Loomis, A., \& Herrling, P. (1993). Courseintegrated honors instruction--pros and cons. In L. Shirato (Ed.), National LOEX library instruction conference: What is good instruction now?. Ann Arbor, MI: Pierian Press.

Love, E., \& Edwards, M. B. (2009). Forging inroads between libraries and academic, multicultural and student services. Reference Services Review, 37(1), 20-29. doi: 10.1108/00907320910934968.

Machin, A. I., Harding, A., \& Derbyshire, J. (2009). Enhancing the student experience through effective collaboration: A case study. New Review of Academic Librarianship, 15(2), 145-159.

Mounce, M. (2010). Working together: Academic librarians and faculty collaborating to improve students' information literacy skills: A literature review 2000-2009. Reference Librarian, 51 (4), 300-320. doi: 10.1080/02763877.2010.501420.

Paul, R., Elder, L., \& Foundation for Critical, Thinking. (2009). The miniature guide to critical thinking: Concepts and tools. Dillon Beach, Calif.: Foundation for Critical Thinking.

Raspa, R., \& Ward, D. (2000). The collaborative imperative : Librarians and faculty working together in the information universe. Chicago: Association of College and Research Libraries.

Riehle, C. F. (2008). Partnering and programming for undergraduate honors students. Reference Services Review, 36(1), 48-60. doi: 10.1108/00907320810852023.
Simon, Carol. (2009). Graduate Business students and business information literacy: A novel approach. Journal of Business \& Finance Librarianship, 14(3), 248-267.

Snavely, L. L., \& Wright, C. A. (2003). Research portfolio use in undergraduate honors education: Assessment tool and model for future work. Journal of Academic Librarianship, 29(5), 298-303. doi: 10.1016/ S0099-1333(03)00069-7.

Swartz, P. S., Carlisle, B. A., \& Uyeki, E. C. (2007). Libraries and student affairs: Partners for student success. Reference Services Review, 35(1), 109-122. doi: 10.1108/00907320710729409.

Tooman, C., \& Sibthorpe, J. (2012). A sustainable approach to teaching information literacy: Reaching the masses online. Journal of Business \& Finance Librarianship, 17(1), 77-94. doi: 10.1080/08963568.2012.629556.

University of Louisville. (2012a). Ideas to action: Using critical thinking to foster student learning and community engagement. Retrieved April 23, 2012, from http://louisville.edu/ideastoaction.

University of Louisville. (2012b). University honors program. Retrieved May 5, 2012, from http://louisville.edu/honors/.

Wilson, M. C., \& Mulcahy, K. (1987). To better the best and brightest undergraduates. College \& Research Libraries News, 48 (11), 700, 702-203.

Witt, S. W., \& Dickinson, J. B. (2003). Teaching teachers to teach: Collaborating with a university education department to teach skills in information literacy pedagogy. Behavioral \& Social Sciences Librarian, 22(1), 75-95. doi: 10.1300/ 
J103v22n01 06.

Woodard, P. (1996). Librarian and faculty collaboration in honors 301.88: An interdisciplinary computer applications course. Research Strategies, 14(3), 132-144.

Yee, S. G. (1984). The role of the academic library in a university honors program. Paper presented at the Annual Meeting of the Michigan Academy of Arts, Science and Letters. 